\title{
Postencephalitic parkinsonism
}

\author{
H. Alva Blackstone \\ University of Nebraska Medical Center
}

This manuscript is historical in nature and may not reflect current medical research and practice. Search PubMed for current research.

Follow this and additional works at: https://digitalcommons.unmc.edu/mdtheses

Part of the Medical Education Commons

\section{Recommended Citation}

Blackstone, H. Alva, "Postencephalitic parkinsonism" (1931). MD Theses. 141.

https://digitalcommons.unmc.edu/mdtheses/141

This Thesis is brought to you for free and open access by the Special Collections at DigitalCommons@UNMC. It has been accepted for inclusion in MD Theses by an authorized administrator of DigitalCommons@UNMC. For more information, please contact digitalcommons@unmc.edu. 
SENIOR THESIS

H. Alva Blackstone. 


\section{POSTENCEPHALITIC PARK NTSOMISH \\ WITI \\ CAST REPORTS \\ 1931.}


POSTENCEFHA LITIC PARKNWSONIST

This condition may be differently spoken of as mesencephalitic Parizinsonism or as chronic encephalitis lethargica axhibiting a Parkins on's syndrome. It is also known as encephalitic or postencophalitic paralysis egitaus.

The Parkinsonisn of pos tencephalitis is considered generally as a sequel of acute epidemic encephalitis. Iater studies, clinically and pathologically, have given rise to the belief that a parkinsonism following encephalitis (acute epidemic) may not be a sequel, but a symptom syndrome due to chronic inflammatory changes which are a part of the acute encephalitic entity.

For the sake of past $s$ tudies of the disease, it sheII be considered for the present es a sequel of acute epidemic encephalitis wi th a pathology of degeneration changes in the basal ganglia. Subsequent facts are to be presented in support of more recent interpretation, ie., chronic inflamatory process.

Postencephalitic Parkinsonism is very probably an incurable disaase state which nay appear any time after an attack of the acute disease. From the infant of two or three weels to the person of eighty years no one is exempt. It would seem that the teen-age and the young adult are nore often efflicted.

The disease is characterized by the insidious onset of tremor, musculer rigidity and weakness, giving rise to a peculiar gait, attitude and facial expressions. Sialorrhes and rigidity, also, particulary mark the Parkins onism of pos tencephalitis. This syndrome may come on immediately after the onset of the acute epidemic encophalitis, or even after two to four years. There 
my be a prodromal attack of Parkinsonian symptoms as the lethargy of the primary disease clears, followed by a quiescent period, that is ended by a typical syndrome of Parkinsonism.

Since this postencephalitic sequel embodies the necessity of a previous attack of encephajitis of the acute epidemic or lethargica type, it is reasonable to note some of the defining characteristics of that disease. It nust be lnown, however, that very typical cases of postencephalitic Parkinsonism exist without a truly diagnosed preceding encephalitis lethargica. Von Economo in 1918 summarized and ably defined the us ual symptoms of cases seen then. He noted three stages or types of the primary disease entity, namely (1) In the first there were fever, delirium and hyponania for one or more days. (2) Then followed a variable period of a few days to many weeks during which there was marked hyperactivity, often associated wi th insomia, choreic or athetosic manifestations and myoclonus. (3) Finally the pationts lapsed into a lethorgic state during wich there palsies of the cranial nerves, associated with bulbar and cerebellar symptoms.

The exceadingly great variations, however, in the individual cases rerder this outline of little or no value, except as a study locus. Wany patients exhibit but one or two of the three stages; others present a remarioble paucity of diagnostic data until postencephalitic menifestations are seen.

No attack of acute opidemic encephalitis is too slight to be free from late effects, and the interval or the period of aparent complete recovery is often as long as three years or longer, and on the other hand there my be no interval, the acute picture nerging into the chronic state imperceptively.

The first epidenic of encephalitis followed in the wake of 
of the great epidemic of influenze which swept over the world. From the fact that each succeeding crop of cases varied to some extent from the preceding one, that varying sequels attend different outbreaks and that the disease has become somewat milder, it is inferred that the causative agent has unaergone some mutation or attenuation. Thus, in derining the rather protean encephalitis lethargica, a better understancing of its sequellae can be had. The background of postencephalitic Parkinsonism becomes more distinct in the light of an interpretation of the primery disease entity.

A. W. (47) Young has noted that in thirty-nine selected cases of postencophalitic Parinsonism, that the symptoms at the time of the original illness consistad of somolence in twenty-six cases, diplopia in nineteen, deIirium in eleven, restlessness in six, headache in five and gidiness in two. Fur ther, that the interval between the original iliness and the onset of the Parkinsonian symptoms anounted to four years and four nonths as a maximum; in eightoen cases no interval was nuted. Ihe average interval then worked out as 7.2 months.

In the past many ceses of Parrinsonism with absence of, or poorly traced etiology, could have in all probability, been attributed to encephelitis lethargica.

Acute epidemic encephalitis or encephalitis lethargica has beon known of in varying degrees of definition and clarity since the time of Galen and Hippocrates. There are records of outbreaiss suggesting this disease in 1712 in Gerrany and in 1890 in parts of southern Europe. (To which the name Nona was given). Until Von Econorno recognizad it as a disease entity and described its clinical types in 191718, it had baen known as Mona. It had been partly recogmized and discussed after the pendemic of influenze of 1889-1892. 
Parkinson's original description of his syndrome in 1817

was basgd on observation of chiefly aged patients, whose symptoms were a ue to senile changes, ie., idiopathic paralys is agitans.

Interest in the sequeliae of acute epidenic encephalitis has been trensferred from Vor wconomo's reports in the spring of 1917 at Vienna, on to France in 1918, Englend in 1918-1919 and to our own shores in 1919-1920. Ihis meriss somethat the path of the epidomic spread of the disease, although all parts of the world were touched and left narkod by cases of postenoephalitic paralysis agitans. The acute epidemic encephalitis touched Austria and france in 1916, England in the spring of 1918 and was recognized in the United states about the end of 1918. Reports of sequellae appeared after about one year as previous ly noted.

In sngland and wales there were 1470 cases of the acute disease in 1921, and in rrance it is estinated that there were 10,000 cases up to 1920 .

In earlier reports on encephalitis lethargica, it apparently peralleled the influenza epidenios of 1917 and 1919. There has been no proven likeness or interdependence in their etiology.

Males and females are attacked in about equal numbers.

This is in contradistinction to Parkinson's paralysis agitans, in wich nales were stricken twice as frequently as females.

In striking contrast to polionyelitis it is rare in young children and nost common in young adults. Cases net today are chiefly in the age renge of twenty to thixty-five years. (1931). Cases in patients over the age of fifty are not uncommon, however.

It seems true that from forty to sixty percent of cases of acute epideric oncephalitis sooner or later menifest parkinsonist. 
Chromic sncephalitic Earinsonism not infrequently makes its first appearance wi th pregnanoy and if present may be aggravated by it. (5) $(10)$

Heredity nor feoblemindedness seom not to heve any influence upon the incidence of the disease.

Although cases occur sporadically throughout the entire year, the greatest number have alweys occurred during the winter months. $(48)$ Charted incidence of cases point to December and Januery as pear months. Head colds, grippe and influenzae are active then, also, but no proven alliance has been cited.

Incephalitis lethargica is undoubtedy infectious, but herdy contagious. The very rare occurrence of more than one case in a family can better be explained on the ground of coincidance. Nor has direct contagion been observed in hospital wards.

Cases of postencephalitic sequellae when grouped show rather high incidence of Parkinsonism, pure or mixed. Riley cites 129 cases(35) 70 of which were Parkins onian type. Another set of 92 cases reveals 42 paralys is agitans syouromes.

(17) Hill reports 67 cases of postencephalitic sequellae with26 behaviour disorder cases; 25 prue Parininsonian ceses; 9 a mixture of these two and 5 mith serious mental retaration. Thus 32 out of $67 f$ cases can be said to fall within the scope of this aiscussion. Obviously, postencephalitic Parinsonism depends for its existence on a previous attack of encophalitis lethargica, whether nild or severeand whether diegnosed or not.

(47) Of A. Woung's 39 cases of proven psotencephalitic Parkinsonism, all gave an account of earlier illness, diagnosed at the time as encephalitis lethergica in 29 instances, influenza in 5 , rheumatic fever in 2, and appenoicitis in one. Ono patient had no 
previous illness.

(12) Eaves and Croll ist ten selected cases of postencephalitic paralys is agitans, 3 of which were not diagnosed as chronic epidemic encephalitis until Parkins on is m appearea.

The frequent occurrence of the parixinsonian syndrome coincident with the recent world-wide eptdemic of encephalitis lethargica has called attention to the important role wich this infection plays in the reoduction of a special type of paralys is agitans. Unquestionably many of the cases occuring in young adults not here tofore unders tood were due to a mild encephalitis which, occuring several years before, had ressed unnoticed.

Whether we choose to interpret postencephalitic Parkinsonism as a sequel of the acute epidemic form of encephalitis or as a nanifestation of inflametory changes which are a part of chronic stages of the disease, we may well look further into the etiology of the acute disease entity.

Several different organisms have been described and held responsible for the infections. However, no one of these has been generally accepted. In the past, encephalitis of this type has been associated with or has followed epidemics of influenza. This is without any proven perelleiism of diseases or any apparent gradation of virulence of organism.

No known etiological factor seems to play a part in the incidence, communication, contagion or spread of the disease. (42) Wechsler admits that the cause of epidemic encephalitis is unknom, but states that we mey assume that the causative agent is a filtrable virus. Strauss and lowe in this country have described 
and ultramicroscopic virus wich they isolated from the nose and throat whings and brains of patients who hed encephalitis, and succeeded in transmitting the disease to aninals thru several generations. Part of this work has been confirmed by McIntosh and Turnbull, Ievediti and Harvier, Ottolengini, Doerr, and King, but no one has beon alle to grow the organism in cultures. In view of the fact that, as has been definitely show, rebbits and monkeys are apt to develop, spontaneous ly or through infection, encephalitis closely simulating the epidenic form, animal experimentation with the virus loses much of its force.

Rosenow is of the opinion that encephalitis is caused by a strepto coccus. He has produced almost as good evidence as other experimenters, but, like them, he failed to prove his case. It was variously believed that the virus of encephalitis is closely related to that of polionyelitis, but neither the symptonatology nor the epidemiology support this view. Nor can the polionyelitis virus be neutralized with convalescent encephalitis serum, al though Neus tad ter is convinced to the contrary. The relationship of encephalitis to influenze has also been discussed, but hore again temporal association is interpreted as a causal Iink. The occurrence of "Nona" which bore some reserblance to encephalitis, arter the great epidenic of influenze in 1890 , is adduced as further proof of the relationship of the two aiseases. If we admit the truth; we do not now. The work of Szymenowsi and Zilberblast-Zand identified the relationship of encephalitis and herpes febrilis. The same cannot be said of chickenpox, though here to the speculation is plentiful. To sum up, epidemic encephelitis seens to be clinically and epidemiologically a fairly distinct entity. It is quite possible that the virus stands in some 
biologic relationship with other viruses, but proof is entirely leoking. Whether we are dealing with some mutation forms can only be guessed at for the present.

(25) In 1919, Rosenow began his study of the etiology of epidenic encephalitis. With a somewhat peculiar strepto coccus isolated from infected tonsils, teeth and nasopharynx he succesded in producing typical symptoms and lesions of encephalitis in animals. Although the various strains isolated were of low vimulence, they had considerable antigenic powar. Rabbits were successfully imnunized following the injoction of homologous and certain heterogonous strains. On the bas is of these determinations treatment by active immunization (vaccine) has been tried in the more chronic types of the disease, with a view to preventing recurrences and sequeliae. No dependable data are available concerning the efficacy of treatrent by vaccine. On the basis of letters receivod from patients and their farily physicians apparenty little can be expected. (Mayo clinic's Correspondence) After all these considerations no single etiological or contributing fector can be citod as a causative agent. (29) We must agree with osler and Macrae that the cause is unimown. Whether virus or streptococcus; we have no legitamate proof on inich to base a positive statement.

That a true postoncephalitic Parkinson's syndrome may follow an atack of the acute entity is apparent whether the acute attack be severe or mild, aiegnosed or unrecognized.

The pathology of a Perkinson's syndrome following epidemic encephalitis has given rise to considerable discussion and research. The chief cause of this, in all probability was the deerth of cases coming to autopsy. In 1925 (Fabruary) when Hohnen read his paper (18) before the Johns Hopkins Hedical Society, there had been but 20 cases 
authenticelly reportgd, and those in groups of one or two.

Meny of the early cases which became study: material for the pathologist, were older persons where senile chenges of degeneration and arteriosclerosis complicated the picture. Ia iopathic paralysis agitans cases were also confused with the postencephalitic ones. Wore recently, proven cases of postencephalitic Parkinsonism have come to autopsy, which have been frow the young acult group insofar as the primary infoction was concerned. These give the best possible opportunity for checking clinical findings against pathological data.. Dariy pathological interpretations of this Parinsonism of postencephalitis were based on the findings of true paralysis agitans. Hence the belief that Parkinson's synarone following acute epidemic encephalitis was only a sequel and represented idiopathic changes of the brain stom.

At prosent, the pathologists are rather generally agreed that the brain tissue changes of chronic encephalitic paralysis agitans are of inflammetory origin and represant both acute and chronic stages of activity of the original infection. There is controversy still, however, as to the exact site of the chief lesion of postencephalitic Parins on ist. The location of the lesions of the various other manifestations of chronic encephalitis lethargica also give much naterial to current literature.

We now turn to the various investigations of the pathology of this disease, for their decisions and findings. They represent recent, and nore remote studies of autopsy material.

(18)Eohman, working in Prof. Harburgs laboratory at the Neurological Institute of Vienna was able to confirm the nost of the findings of investigators (a) that the mocess, is a very widespreas one which involves prectically every part of the central nervous system - cortex, 
basal ganglia, mid brain, cerebellun, medulla, and cord, with especial localization in the basal ganglia and midorain tegmental structures; and (b) that the process affects the parenchyma primarily and the cell changes are for the nost part of the severs chronic degenerative sort with cell shrinkage, and solerosis, on the one hand, and cell dissolution, on the other, with neuronphagia. Along with this constent picture of chronic degeneration Hohman als o found more acute al teration With swelling and axonel alteration. The nerve fibers were found to show all stages from acute swelling to a complete resorption of large areas of whito natter. The process may be a loss of melin in a sore whe discontinuous fashion or a more radical loss resulting in a cribriform appearance. This formation of holes in the tissues may or may not implicate blood vessels. The glia were, on the whole, found to show surprisingly little activity. Hohran found some increased activity about the blood vessels with the production of glia ribers, but in general the glial increas was manly cellular, manifesting itself diffusely or in the formetion of snall gila nodules:

Hohmen fur ther found that the mesenchymel elenents gave relatively little evidence of change. There was some slight thickening and the appearance of calcereous deposits in the wells of blood ressels, which he could not account for by the age of the patients. The pia also gave evidence of irritation with minimal evidences of moningitis.

A most striling feature was the univers la finding in Hohnen?s cases of persistent signs of acute and subacute inflemnatory reaction even arter nonths or years of the disease. In every case where diligent search wos instituted, he found depinite areas of round-cell infiltration with plasma cells and lymphocytes. In some cases he had to search through many sections before finding it, 
but it was alweys present. Sometimes when infiltretion was massive, he found an occasional polymorphonuclear leucoeyte as proof of the relative acuteness of the process. The infiltration was noted to be almost exclusively perivascular. No part of the nervous sys tem wes thought to escape this inflammatory process from cortex to cord. He also found a striking fatly change in cells, which varied from a mere lipoid. increase to fatty aystrophy. Even taking into account the fact that the patient as a result of prolonged illness associated with difficulties in deglution were profoundly marantic, the fatty changes were deemo out of proportion to the amount one could expect from this cause.

Hohman states that the schools of neuropathologis ts who have studied the akinetic hypertonicity syndrome of parisins on have dealt with, for the nost part, senile breins. These investigators, Ied by the Vogts and Rensey Eunt, had been impressed with the lesions in the globu palidus and large cells of the caudate and putanen. The french School of Pierre Marie and his pupil pretiakoff, on the other hand, in their study of the syndrome in seile ceses and in postencephalitic cases had postulated the nost important lesion in the substantis nigra.

There had been prectical agreement by all other authors, that in cases of encephalitic Farkins onism described up to date, (Fohmen, 1925) the substantia nigra was the most rofoundy involved. Hohnan thinks, however, that there is no necessity for believing that both sides may not be correct, and that the localization in the two diseases is not different. Fe notes that the fact that, whatever the pathways involved in the extra-pyranical synoromes, they are constituted by a number of links, wold make it easy to uncerstand that an interruption at one of several places might result in the 
same final outcome.

Having localized the pathological lesion of postencephalitic Parkinsonism, Hohman reports that in all his cases ( 12 reports), there was most profound and constant dogeneration in the substantia nigra. The degeneration in the substantia nigre as he describes it, is manifested by the disappearance of every great number of the large pigmented cells, destruction of miny of the fibers and an increase of the glial elements with pignent inclusions and pigment masses lying free in the tissues. Furher, cases were found in wich the pallidun was practically intact. Next in order of severity of involvement was the striatum (putarnen and candatus) and then, thirdig, pallidum cerebral cortex, the mid-brain tegmental structures, (nucleus interstitialis, and nucleus ruberl; then the cerebellum with the dentate, the nuclei of the medulla (dorsal vagus nucleus and anbiguus) and, finaly, the cord. Hohnen's summary suggests that the correct concept of the histopathology of postencephalitic Parinson's syndrome is found to consist in:

(a) An essentially chronic degenerative perenchymatous process with constant persistent evidences of inflamatory reaction.

(b) Tidespread distribution of the lesions in every part of the central nerrous system.

(c) The region of maximal and constant involverent is the substantia nigra.

Other authorities are to be quotec that we may get a conception of the protean understanding of the pathology of the acute to chronic encephalitis exhibiting Parkinson's syadrome. (6) Fawin Bramell, considering the pathology of encephalitis le thargica feels thet the anatomical considerations cenonstrate that this affection is dependent on an encephalitis which shovs a 
speciel though not invariable predilection for the brain-stam.

In discussing the symptom of trenor, olendening(f)notes thet it is met in a sequel of epidemic encephalitis. He also ssserts that this dystinesia of encephalitis is due to a lesion or Iesions in tho corpra striata.

(12) Eaves and Croll in a study of ten cases finc great destruction of nerve-cells, especially in the substantia nigra in which there was practically totel disappearance of the nerve-cells and an increase of the neuroglia. They also mention perivascular round cell infiltration. Nany iibers were obviously abnomal, as they presented varicosities and constrictions, the appearance being similar to the'beaded'effect observed by Alpine in the substantia nigra of other cases. Hhey sumarize by stating that the hypothalmic region of the brain in chronic epidemic encephalitis is more severely affected than any other area except the substantia nigre of the mid brain region. The change in the two regions are usually though not inveriably paraliel.

(28) Wichels, creighton pethologist recently (1929) found that as far as poliomyelitis and encephalitis aro concerned, vascular endothe lium cannot be held responsible for the production of the exudate cells met with in the lesions ocourring in the central nervous system. On the contrary, the vast majority of the infiltration cells represent recently emigreted Iymphooytes and large mononuclears, with a cuota to be interpreted as homoplas tic derivatives of previously extravasated Iymphoid cells. This finding would seam to fevor the presence of the acute or subacute inflanmatory processes wich are met in chronic encephalitic paralysis agitans.

$$
\text { (13) F. G. Bbaugh is considering the pathology of chronic }
$$
epidomic encophalitis has noted that tho besal gangila show peren- 
chymatous changes to a marked degree, but that there are also severe interstitial changes consisting of intense perivascular infiltration mainly of lymphocytes and plasma cells - confined at times to the Virchow - Robin spaces, but at other times flowing over into the tissue substance. He points out that in places it can be made out, as in the region of the substantia nigra, that the tissue itself is invaded by these cellular elements. Although this opinion is aute Iike previous anthorities cited, it adds one supporter to the side of chronic inflammatory changes in Postencephalitic Parkinsonisn. (46) Wood considers both past and present conceptions of the pathology of Parkinsonisms of chronic lothargic encophalitis. He notes that the first investigations of these cases suggested that the pathological condition was due to a selective atrophy of the notor celis of the pallidal syster. Subsequent studies, he points out, have shown that the lesion is situated chiefly in the substantia nigra and that the changes in the globus paliidus are to be considered secondary to those of this region or merely incidental findings. Whis authority finds that still further investigations have show that the Iesions are often moch nore extensive, involving the internal capsule, thalamus, candato nucleus, and the frontal 10be. Under these circunstances, he feels thet careful quantitative estimations of the cellular changes are important and it hes been found that in three cases of pos tencephalitic paralys is and average decrease in the number of nevrons from 57 to $87 \%$ has occurred in the substantia nigre without significant lasions in the globus palidus. Wood mentions here that it is interesting to note at this point, thet in patients with a general paralys is definite pathological changes have been found in the basal ganglia, which may be responsible for the inexpressive facies 
and the fine tremors about the mouth and eyes occasionally seen in this disease. (Posten. Park.)

Wood has embodied in his considerations of the pathology of postence phalitic parinsonism sone recent interpretations of its pathology. He states that sone observers consider the classio parkinsonitm lesion a chronic progressive degenerative condition of the entire central nervous system; a position that is well supported by the clinical symptoms in advanced cases and that it is not, therefore, proper to iook on paralys is agitans merely as an end-result of encephalitis. Jvidently under this general title there are numerous closely related clinical conditions associated together, of hich the clessic paralys is agitans is due to a degenerative type of lesion involving the extra-pyramidal syster, mainly the basal ganglia and especially the substantia nigra, while the lesion in the postencephelitic synarome though degenerative in a degreg, is also conbined wh inflanmatory phenoraena.

Thus, through the pathologieal findings of this disease we motate that the present conception of postencephalitic Parxins onism is that its symptom syndrone is due to chronio progressive inflamuatory processes in acute and subacute stages 酸ich are a pert of the pimary encephalitis. Hence, the standing of postencephalitic paralysis agitans as a sequol of encephalitis lothargica loses stability in the light of recent autopsy findings.

The symptomatology of idiopathic peralys is agitans and of postenoephalitic Parikinsonista is nearly icentical. If we exlude for the monent the rapidity of onset, wich in the idioptahic type of paralysis agitans is slow and in the ancephalitic type is either acute or insiaious following the disease, the two conditions present parallel findings and signs. 
At first tremor appears in one limb or only in the fingers or toes, or even in the thumb above or little finger. This tremor generaliy is rhythmic, fine, or moderate; it may be one of flexion or extension, adduction or abduction, pronation or supination, with a rate of four or five to the second. There is a certain stereotypy to it. It used to be eraphically described as "pill rolling" in character, after this particular phamaceutical maneuver. The tremor is frequently one of rest, but not always, is momentarily stopped by effort or voluntary movement, and aggravated by emotion. It generaliy ceases at night. It may cease spontaneously for a while, and then resume the restless oscillations. Generally, the tremor spreads up one limb, gradually involves another, possibly becomes limited to one side for a time (hemiparkinson), but finally involves the other limbs. Very characteristic when present is a tremor of the jaw. Occasionally there is tremor of the tongue. The head partakes of the general body tremor, but isolated shakings of the head, such as is seen, for instance, in multiple sclerosis, does not occur. Occasionally tremor is altogether absent; wherefore the name paralysis agitans sine agitone. This is not uncommon in the postencephalitic type. Very rarely one may obaerve tremor of the eyelids, more often in the encephalitic cases. Setting in at the same time with the tremor, very often preceding it and usually constituting the most significant feature of paralysis agitans, is a change in the attitude or posture and the movements of the patient. The arm in which tremor has already set in or or will ultimately develop does not swing in walking. There is no paralysis, but associated movements of the arms are impaired or lost. 
Soon after the other arm fails to move automatically in walking. The face begins to lose its mobile emotional expression, its conative activity In mimiory and gesture, in laughing and crying; it becomes ironed out, waxy, mask-Iike (early in encephalitis) rigid. The eyelids may be only partly opened, giving rise to a sleepy expression. The head tends to bend forward, the shoulders begin to stoop, the body to flex anterior1y. The arms are extended and adducted, the forearms are somewhat flexed at the elbow, the hands are flexed, the distal phalanges extended and the fingers adducted. (It is said that very seldom there is extension of the body and extremities instead of flexion.l The gait becomes slowed the steps are short; rising from a chair or sitting down is done seemlingly with deliberation. All movements are slowed, but there is especial Ioss of initiation. Underlying all this is a gradually increasing rigidity of the body musculature. Wigton, Boston, and Anders note this rigidity as more typical of early postencephalitic Parkinsonism than the tremor. The patient walks and moves as if in one piece. On attempting to walk there is a certain hesitation, as if the person was rooted to the ground, then festination. With this there may be rapid pulling of the body forward, propulsion, or backward, retropulsion, or sidewise, laterpulsion, so that the gait becomes accelerated. Forward movements of such a patient is characterized as giving the appearance that the patient is continualiy crasing his center of gravity which just does manage to keep ahead of him.

The want of associated movements and changes in posture and tonus represent the most characteristic features of paralysis asitans. This applies to the encephalitic variety especially the increased tonus or rigidity. In a study of several cases vechsier and Brock came to the conolusion that the loss of the so-called automatic 
movements adn the postural disturbances regresent the loss of a stellreflex or righting reflex, as conceived by thagnus and de thlijn. This Ioss of postural reflex may be observed even in patients whose bodily musculature does not show hypertonie or rigidity. Ganeraliy, hovever, the rigidity is narked, and one mey elicit the cogwhes phenomenon on suddenly trying to overcone the rigidity of the flexed forearm. Sometimes the Souque sign can be demonstreted: Sucdenly throwing the datient back wile he is sitting in a chair, the lower extrenities fail to kick out or extend as they do normally. Occasionally micrographia is a characteristic sign of paralys is agitans, clessic or encephelitic types. Wile there is not any actual paralys is roluntary motor power is Iowed and performed with effort. This may be pertly due to atrophy of musle fibers although that seems to be a very slowly progressive change. It is only in the very late steges that real paralys is or pares is may be observed. The eyebells more slowly, the eyelids rareIy blink; but if the patient is asked to look quickly to one side or the other winking may occasionally be observed (tilson). The deep reflexes are preserved, the abominal reflexes are present and lively, and there is no Babinski sign. This latter applies to the idiopathic tyoe, wilo in the encephalitic paralysis agitans the Babinski is frequently positive. Similarly, there are no pupillaxy anomalias, no crania nerve palsies, no sensory dis turbances, again excepting chronic encephalitic maniestations to the contraty, and posibly erteriosclerotic cases.

As the condition progresses the rigidity becones nore marked and the trenor Fidespread and intense; the patient complains of tireaness and frequently of dull but severe peins which keap him aweire at night. Gredually the speech becones monotonous, and toward the and 
true dysarthria and even dysphagia may be present. There are no bladder disturbances, except toward the very end. Trophic and vasomotor disturbances, are not common. A feeling of heat, perspiration cyanosis of the extremities, localized edema, and atrophy of the muscles of the hand may be observed. The mentality is normal, al though the patient is often depressed, naturally by the illness. Nevertheless, in senile, arteriosclerotic, and especially in encephalitic cases, delusional paranoid trends may be observed $(19)$ tbaugh especially notes behavior disorders in chilaren which are inversely proportional in seriousness to the intensity of the Parkinsonism. Salivation or sialorrhea is frequently a distressing symptom and is almost pathognomonic of postencephalitis as noted by Wigton. $(44)$ Excessive sweating may be occasionally encountered. Finaliy muscular contractures, especialiy of the hands and feet, develop on the basis of muscular rigidities.

Laboratory findings as generaliy reported and as we have found in a study of our own hospital cases are essentially negative. The spinal fluid may show an increased glucose content and also a paretic colloidal gold curve. The cell count in the spinal fluid is rarely abnormally increased in postencephalitic Parkinsonism, nor is the globulin content ever more than slightly raised.

The diagnosis of a case of postencephalitic Parkinsonism is relatively easy. First, one should attempt to get a history of the acute epidemic encephalitic attack. Whis history may not be typical nor will the case, in all probability, have been diagnosed as encephalitis at the time. An attempt should be made to find out if there was an illness in which suppression of urine for one to three days occurred and if there was a period of 40 to 150 hours of failure to sleep or of inability to keep awake. the patient should be asked concerning eye tremors, lid tremors, difficulty in swallowing and in speech at the time of the acute attack. Inis attack will have preceded 
the development of the chronic syndrome by from a few days to seven or more years.

The paralysis agitans syndrome of encephalitis lethargica having established itself with tremor or more probably without, the diagnosis then turns to the features of the typical case. The syndrome may have set in acutely, have developed during the illness or have appeared after a variable latent period. Rigidity of the body and limbs will have been noted as interferring with the usual tasks. PosturaI disturbance and abnomal gait will be noted. There will be impaiment of associated movements. An inability to laugh or cry ie.; "mask-facies" will be noted or complained of by the patient. The handwriting will be slow, irregular and the letters will be very small and cramped. Frequently an oily skin or oily hair will be a complaint in the syndrome. Drooling of saliva will often be a bitter complaint coming from the patient.

Various other postencephalitic manifestations may add to or nearly obsure the Parkinson syndrome. These will be noted further on.

(Q)Boston and Anders state that in the Parixinsonism of postencephalitis the tremor is less constant than in the idiopathic type. Elso that in this hypokinetic or akinesic manifestation of chronic encephalitis the increase of the plastic tone is usually much greater than that noted in the idiopthic paralysis agitans.

(4) Wigton, in a personal statement in our Dispensary neurological clinic, states that rigidity and sialorrhea in a Parkinsonian syndrome with reasonable evidence of a previous attack of encephalitis lethargica are pathognomonic of postencephalitic paralysis agitans while tremor characterizes the olassic Parkinson's disease. There seems to be no typical diagnostic therapeutic test. 
(10)(21) Ornsteen describes three signs that aid the early diagnosis of chronic encephalitic Parkinsonism. In the first test, with patient standing at attention, though relaxed, in early Parkinsonism the hand on the affected side shows an increase in the degree of flexion of the interphalangeal joints. In the second test, a finger-spacing test, there is definite asymmetry between the two hands, with greater irregularity of the spacing of the affected hand. In the third test, when . the fore-finger is touched rapidly and repeatedly to the thumb, with hands held up in front of the face, there is a definite limitation. of agility in the movement and reduction in amplitude on the affected side.

Differentiation of the postencephalitic Parkinsonism from the classic paralysis agitans has been given. In the former, rigidity and sialorrhea are in comparison to the marked tremor of the latter. Pathologically the lesion of the former is in the substantia nigra while that of the latter is a degenerative lesion in the globus pallidus. The acute and chronic manifestations and the sequellae of epidemic encephalitis may similate practically every basal ganglion syndrome.

$$
\text { Syphilis may cause a syndrome of paralysis agitans. It is }
$$
ruled out of the present consideration by a history of previous acute epidemic encephalitis which is a pretty general differential necessity. The blood wassermann test would be needed.

The cysticercus has been proven to be the cause of a unilateral paralysis agitans by Oppenheim. Ruled out by the absence of eosinophylia and a history of acute encephalitis.

Thet arteriosclerotic paralysis agitans of past midale age would be ruled out by the age, the rapidity of onset, the mental symptoms and history of the acute entity. 
Carbon monoxide poisoning may cause symmetric softening of the leuticular nuclei (pallidus) with a resulting syndrome of paralysis agitans. This could be verified by a history of the exposure to the gas, or on the other, a history of encephalitis lethargica.

Very rarely a patch of multiple sclerosis in the basal ganglia may also give rise to a syndrome of paralysis agitans, but the usual atoxic tremor and the signs of dissemination, together with the remissions, speak for the multiple sclerosis.

The tremor seen in hysteria, more particularly traumatic neurosis, with an acute onset, emotional background, psychotic origin, and the absence of rigidity, rule out the organic entity.

(19) (99) Hoffman, Wohlwill, and Schuster report cases of frontal brain tumor with Parkinsonian Symptoms, in which the chronic encephalitis entity was ruled out by spinal fluid pressure readings and later by histological research.(99)sehuster found that in his two cases the tumor did not exist, but that there was basal ganglia changes of undetermined origin.

(2) Eostencephalitic manifestations may be grouped, viz:

(a) Hypokinetic state (the present study).

(b) Hyperkinetic states such as tic movements, choreiform and athetoid, and epileptiform states, localized spasms, torsion spasms and (31) hyoclonia are frequently encountered. But of greater interest are those involving the respiratory mechanism seen especially in children. This variety has only lately received special attention and was regarded at first as rare and frequently labelled hysterical in nature. These disturbances are seen as disorders of the respiratory rate (tachypnoea and bradypnoea); dysrythmias, or disorders of the respiratory rhythm (Cheyne-Stokes breathing, breathing-holding spells, sighs, forced or nois expirations, inversion of the inspiration-expiration ratio); respiratory 
ties (yawning, hiccough, spasmodic cough, sniffling). Associated with these respiratory disturbances are exaggerated movements of the accessory muscles of respiration, face, limbs and entire body producing the most bizzare pictures (hence the frequent labelling of hysterical). Lesions here are reported as being found in the upper part of the medulla oblongata. The proportion of recovery cases from respiratory, disturbances appears to be greater in the cases with a progressive Parkinsonian state than in those without the manifestation of paralysis agitans.(15)

(c) Hyperalgesia sequellae consisting of pains and dysesthesias in all parts of the body accompanied by marked emotional over-reaction.

(d) Disturbances of the sleep mechanism as insornia, diurnal somnolence, and inversion of the day-night cycle.

(e) Dyspituitarism usually hypofunctional in character, and often of the Froelich's syndrome.

(f) Neurasthenic states and hysterical reaction.

(g) Psychotic trends suggestive of dementia praecox; behavioristic and personality changes, noted especially in children by Ebaugh(13) (16) Hill found that in children attacked by epidemic encephalitis over $70 \%$ of the survivors show some psychological changes and wore than $33 \%$ show behavior disorders.

( h) Various vegetative phenomena such as salivation, polyuria diarrhoea, vasomotor symptoms, tachycardia, asthenia, and syncopal attacks have been reported.

\section{(L) Oculogyric Crises. (33) (23) COURSE AND PROGNOSIS}

The course of the Parkinsonism of chronic encephalitis is chronic Cases are known to have exhibited symptoras of the syndrome, or of the syndrome entire ever since their acute encephalitis seven to ten years ago.

(47) Young studied 50 cases of paralysis agitans, 39 of which were 
postencephalitis. The duration of the Parkinsonism in these postencephalitics was seven years in the longest instance and three months in the shortest, making an average of two years and two months. These cases were reported in 1927 and the condition had not had time to exist longer, ie., there is no reason to expect recovery after 7 or even 20 years. Due to the run down condition, these cases frequently die of pneumonia or other intercurrent disease.

The course is one of slow, insidious progression of rigidity, atrophies and cranial nerve palsies. Active treatment may halt the slow advance.

The prognosis is indeed hopeless in that the chronic inflammatory changes in the basal ganglia seen to progress by acute and subacute exaccerbations. Neurous and glial fibers lost in the substantia nigra show no power or regeneration of substance or function.

Kennedy has emphasized that the outlook in this condition is bad especially in children. Beginning more or less insidiously it progresses until fully developed. He states, however, that having reached this stage in the hild, it appears to come to more or less of a standstill. The general weakness apparently increases, but as most of his child cases, made little effort to exercise, he deems the weakness to be due, at least in part to voluntary inactivity. This would seem to apply to our own dispensary cases which are trying to maintain active convalescence.

In spite of the marked physical impairment and show ing slow reaction time noted in most cases, here and elsewhere, ther is very Iittle effect on the mentality.

Probably, the most to be hoped for in typical cases is an inhibition of the slow progression, whatever, may be the therapy employed. In the acute encephalitis lethargica, if less than $20 \%$ die, at least 60 to $70 \%$ show residual signs and symptoms, some of which are indefinitely 
more tragic and incapacitating than the illness itself.

\section{TREATMENT}

One author in surming up the treatment of acute and chronic states in encephalitis has noted nearly 600 remedies. This at once bespeaks the futility of therapy, especially if specific results are expected.

The treatment is, therefore, basically symptomatic, and palliative. (7) Clendening uses hypodermic injections of hyscine hydrobromide, and gives rather large doses. After an initial dosage of 1/150 grain twice a day and even more if no untoward effects are observed. However, in the cases so treated in our hospital and dispensary early nausea, or tolerance for the drug shortened its efficiency. He has also noted treatment with parathyroid hormone given with calcium lactate and also pituitary extract. He states that they have been given trial but tabulates no results. (14) Scopolamine hydrobromide as well as atropine hydrobromide is servicable in the treatment of the rigidity found in postencephalitis Parkinsonism. At times scopolamine action, at times atropine action, is more advantageous in given cases. Recently, some superiority has been claimed for the use of an allied drug, stranonium, which may be given in the form of a tincture. The accepted maximun dose of 1cc. (15 minims) is far too small and at times as much as 75 minims or 150 drops may be given three times a day. Occasionally, the extract of belladonna in the form of a rectal suppository $0.065 \mathrm{gm}$. (Igrain) to the dose, three times a day, results in the amelioration of the rigidity. All of these drugs should be administered in small doses at first, and the dosage gradually increased to the maximum tolerance of the patient. The tremor is often not diminished by these drugs, but it is claimed that stramonium acts better in this direction. Drs. Wigton and Bennetti in our own hospital and the dispensary service employ the tincture of stramonium 
in these cases. The dos age is by drops, pushing it to to where aryness of the lips and blurring of the vision are notod. One Parinsonism case takes 160 drops thres times a day, wich also controls the lateral gaze (oculogyic) and trenor of the jaw (cranial nerve palsy). She wes in our hospital in November 1930 for 19 days and now visits our dispensary every three weaks. Hex rigidity is well controlled, and checked by an arn raising and lowering test; formerly only 10-12 times in a minute and now up to 30 times.

(6) Bulbocapnine is said to diminish tremor by producing a certain rigidity of the muscles, but results are not universally confirmed. Small doses of veratrun viride and of gelsemin at times diminish tremor. Por the salivation, both hyoscin and atropin may be used. Warm baths and massage give monentary relief; still they are wor th using.

The best kind of occupational therapy is that which is purposeful and gainful. Trenor and rifidity are lessened by jarring and jolting, honce horse back riding, open carriage arivos, auto rides, and travel by rail proves benericial.

(35) The treatment of postencephalitic peralys is agitans wi th typhoid vaccine maybe given, provided not too ruch is expected from it. Hypodermic injections of $500,000,000$ to $1,000,000000$ bacteria every few days mey be tried, but is less effective than smaller coses $(10,000,000$ to $50,000,000)$ intravenous $1 y$ every other day. The object is to get a chill arter each injection. There are favorable results in a few cases, none in most. (38)

Malarial treatrent of postencephalitic rigidities has also been tried. Purther results are needed for comparisions. Patients wi th incapacitating sequelae need institutionalization, as they are a burden to thenselves and their families. 
For, irritability, if present, the bromides may be given Codein nay have to be given for the peinful contrectures, and sometines norphin.

Later experiments have laid aside parathyroid and typhoid therapy as valueless.

General hygiene, the avoidence of irritations and of mantal upsets are to be stressed.

(10) Alford recommends intravenous hypertonic gincose injections in all stages, including the chronic, and says that a majority of the Parkinsonism pationts were benefited.

Tampl gives in detail his method of treating chronic cases during the entire period of treatment the petient takes daily a powder containing scopolanin and calciun lactate. In the beginning of the treatment, fever is induced by the injection of a non-specific protein. A total of six to nine febrile attacks are thus induced. After the last calcium, us ualiy in the form of calcium bandos, is given intravenous $y$ in doses of 100c. Pive or ten injections are given at two or threeday intervals. At the same tive, the administration of atropin is begun and contimud for two or three months. As regards the benefits of this thod, which Iampl clains were considerable, rigidity was relieved to a greater extent than trenor.

(10) Sulfosin is a new drug which Schroeder reports upon vary favorably.

(10) Pouppirt has treated 11 cases with hot baths at a temperature that mintained a fevor of 104 degrees to 205 degrees F for about fourty five minutes. The tremor and the associated pain in the muscles have been helpea, and spasticity lessened. Cacodylate of soda injections have been tried by nany clinicians wichout any remarkable results. 
(21) Electric baths are helpful and tomporarily aiminish tho rigidity; general vibratory massage with the electric vibrator also tend to reduce stiffness and counteract the development of deforming oostures. Faradism of the muscles may also be of value as an exercising agent for the muscles, but, probably is no more beneficial than the massage ô the eloctric vibrator.

The Wagner-Jauragg mothod of treatment of metasyohilis by inoculation trith the tertian type of malaria has been of sone value in the Parizinsonian cases. Intraspinal injection of the serum of convalescent patiants has been advised.

(25) Rosenow's serum obtained from horses, immunizad by repeeted injections of increasing doses of four strains of this worker's peculiar streptococcus, has bean used in the treatment of acute epidenic encephalitis cases at the Meyo Clinic and elsewhere. Of 130 patients treated by Posenow, 85 improved and 43 showed no change. Ther serum has little or no value in the chronic states.

(25)Rocently Roylo, working in Sydney, Austrelia, perporned a series of experiments on goats to deternine the function of the sympathetic ibers supplying the voluntary ruscles, and whether that function had any rolationship to the abnormal muscular condition mot with in spastic paralysis. Fe suggests that the ronoval of the influence of the sympathetic innervation may be of sorre value in certain cases in which disability has resulted from lesions of the corpus striatur, and from disturbances of the upper motor neurone. Hunter is convinced that the relationship of sympathetio inmervation of voluntary muscle to mascular tone has been conclusively proved. Sufficient corroborative wort has been done to prove that these ideas are tenablo, at least in part. If, as seems, probable the rigidity in the Parkinsonian types of encephalitis is due to impulses traveling over the sympethetio system, it may be feasible and ad- 
visable to diminish, by surgical means, the crippling hypertomicity in cases no longer rogressive. Heggan has not had occasion, as yet to try out this type of surgical therapy.

Because imradition has been effective in many inflamatory processes (4h) reutrann and pansdors gmployed it in six cases of chroric encephalitis. The rays were applied on thres fields, two temporel and one occipital. The distance was $40 \mathrm{~cm}$. and the quantity was 10 percent of a unit skin dose. A $0.5 \mathrm{~mm}$. copper filter was used. Whe intervals between irraciations were usually four days. The authors gite the case histories of the six patients who were treated in this nanner. In none of the cases was improvenent noted. Accordingly the authors conclude thet in cases of chronic encephalitis roentgen treatront is not effective. This indicates that inflamatory processes in the brain differ from inflamatious in the other organs. The authors assure that the efficacy of roentgen rays in inflamatious outside of tho central nervous system are due to their mobilizing effect on the function of the supporting tissue; their ineficacy in inflematious of the brain is a ue to the fact that the glia cells do not react to the roentgen ray like other supporting tissues.

(37)Rusetzlyy studied the influence of calcium chloride and magnesium chloride on the muscle tone in ten cases of postencephalitic Parinsonism. He found that calcium chlorice desinitely increases the muscle tone. Magnesium chloride decrease the muscle tone. A nixture of the two solutions causes only a siight relaxation of the ruscle tone. He suggests experimenting with solutions of magnesium chloride in the treatment of sequelae of epidemic encephalitis. Pinally we mist restate the fact that about all the therapeutic treatment can do is to make the patient confortable by treating symptoms, allaying pein and irritabilitias and giving stimulation men needed. W 
cannot hope to cure, but we must attempt to check the insidious progression. SUIMARY

Since the practicing physician or the specialist must concern himself chiefly wi th the living patient, the clinical features of postencephalitis Parkinsonism as a chronic infection are to be stressed. Iruiy enough the student of medicine, though he be in practice must also regard the pathological lesion of his clinical antity. In this paper, considerable authority and experimental data has been set for th to prove the most recent conception of chronic inflammatory changes and degenerative processes in the substantia nigra. Modem pethologists place the histological lesion of postencephalitic paralysis agitans in the substantia nigra. Therefore, we tum in sumary to the clinical features of the lesion whick sogest a chronicity of the infection in the brain:

(a) The gradual appearance and often steady progression of the syndrome many months or several years after an acute encephalitic attack, the patient having, perhaps, been quite well in the interim.

(b) The insidious development of the syndrome with no history of an acute attack (ie. the infection being chronic from the first).

(c) A certain amount of evidence of contagion long after the comencemant of the iliness.

(d) The appearance and variable course in Parkinsonism of other encephalitic signs and symptoms.

(e) The occasional recurrence of the disease in an acute form, perhaps months after the first attack.

Conclusions concerning the clinical features are:

(a) The balance of the evidence must be regardsd as being conclusive of a persistence of infection in the contral nervous system in some cases of Partinsonism. The only means of detecting this is by observing clinical signs of progress of the disease. 
(b) The evidence makes it certain that active infection my be present

for a considerable length of tine before any signs of progress occur.

(c) It is therefore advisable to treat all cases of epidenic encephalitis including those of Earkinsonism, for some years at least after onset, as cases of active infection in the central nervous system.

(d) The aurabla nature of a Parinsonian syndrone once it has appeared, and the destructive signs found in the substantia nigra, indicate that the signs and symptoms at any monent rust be regarded as being almost wholly due to a neuronal destruction, and that no remission of them can be expected from nonspecific or specific treatrent of the active infection, even if it were successiul.

\section{OASES STUDIED OURSIDE}

(1) Mrs. H. M. Age 35. Diagnosis: Postencephalitic Parkinsonism. Courso and Prognosis: Chronic Symptons: Rigidity, tremor, sialorrhea. Onset of encephalitis: 1924 - slept for 18 deys. Ireatment: None.

(2) Mr. 0. M. R. - Bartley, Nebraska - an uncle of the writer. Age 71. Diagnosis: Paralysis agitans, probably postencephalitis.

course and Prognosis: Chronic symptoms. Stmptoms: Rigiaity, sialorrhea, mask-liks facies, peculiar gait, retroantero, and lateropulsion, tranor.

Wr. R. is a great lover of the violin, and upon hearing one playad of lato, his tremor increases and he may ory, but no facial enotion is expressed.

Onset of encephalitis - 1923, diagnosed influenzas and pneumonia stupor. Ireatment: Untreated.

\section{FOSPITAL CASSS REPORTD}

(1) J.J. Age 20 Femele Hospital Aamission Hovember 11, 1924. Dias: Postencephelitic synarome. Dismissed November 21, 1924. - Irproved. Syptoms: slow moderat trenor nore marized in the left hand and arm, than in the right. Onset : Encephalitis. January 1921. Lethargy. ireatment: Hyoscine hydrobromide $\mathrm{gr} \cdot \mathrm{I} / 200 \mathrm{bid}$.

(2) 2 F. F. A. Age 24 Male. December 15, 1924. Diag: Pos tencephalitic Parins on Syndrome. Dismissed January 13, 1925 - semo as on entry. (condition). Syriptoms, iremor of arms and legs. spastic gait. Onset: Acute encephalitis. Severe Flu - 1929 (sleeping) Treatment: Hyscine hyarobromide. gr. 1/100 t.i.d. 
(3) J. D. G. Age I2 years. Male Hosp. Admission Merch 24, 1925 Diag: Postencephalitic synarone.

Dismissed: Hori1 14, 1925. Slow improverient. Symptoms: Hesk like fecies, gait slow. lirenor of hands. Rigidity of legs. Onset: Acute encephalitis. January 15, 1925. Treatrent: Hyos cine gr. I/250 en. 8.00 (Coliy's serum)

(4) ins. S. Age 29 years. Female Hosp. Admission march 12, 1925. Diag: Postence halitis.

Vismissed: April 11, 1925. - Better.

Symptoms: Slow spesch.

Onset Incephalitis - Januery 1925.

ireatrent: 30c0. of mercurochrome intrevenously initial. 10cc. every thirc day.

(5) Mrs. I. M. Age 20 years. Female Hosp. Aomission March II, 1925. Diag: Pos tencephalitis and pregnancy at term.

Dismissed: April 1, 1925. Delivered of beby. Still rigid.

Symptoms: irremor of hands, feet and tongue since 1921 - some muscle rigiaity.

Onset: Incephalitis. Mlus in 1918.

lreatment: None advised.

(6) Mr. T. C. W. Age 25 Male Hosp. Aan. Octo be 1, 1925.

Diag, Postencephalitis.

Dismissed: October 26, 1925. Not improved.

Symptoms: Inability ot sleep: mask like facies. Premor, pill roling

at times. Iead pipe rigicity of arms. Movements slow.

Onset: incephalitis. Hlu 1922. Lethargic at the time for one month

Symptoms of chronic stete came on at once.

Ireatrent: Hyscin, winch he coula not tolerat.

(7) Mr. J. C. Age 54 Male Hosp. Adm. November 11, 1927.

Diag: Postencephalitis.

Dismissed : Decembar 20, 1927. No change.

Symptoms: Mastike face, cogwheel type of movements, rigidity, tremor.

Onset: Incephalitis. Influenza 1919. Very severe with chronic onset in 1922 .

Treatment: Hyos cine hydrobromide one two hundreth of a grain b. i. d.

(8) M. B. P. Age 42. Hosp. Adm. October 25, 1928.

Diag: Postencephalitis.

Dismissed: November 15, 1928. Unimproved.

Symptoms: Tremor, rigidities, slow speech, difficulty in swellowing, salivetion, masklike face,

Onset: Bncephalitis. Sever cold 1925. weak and tired.

Chronic symptoms: 1927. notad slomess in his work.

Treatinent: Hyoseine hydrobromide one one hundredth of a grain b.i.d. 4 injectons of typoid vaccine intravenousiy. Chills.

(9) His. F. 0. Age 36. Fenale Juno 30, 1929.

Dias: Postencephalitis. psychotic reaction.

Dismissed: July $15,1929$.

Symptoms: Parkinsonian slight tromor and rigidity. Pacies fairly inmobile. Posture and gait are.

Onset: Fncephalitis.

Treanent: Sedative. 
(10) H. B. Age 18. Bemale Aduission April 16, 1930. Diag: Postenoephalitis - residual effacts. Dismissad: Slightiy improvad. Symptoms: Waskliko expression. Hendencey to retropulsion. Mystagmus, tremor of tongue, tremor of laft foot and knee. Pill rolling. Atlitude of left hand. Trestment: NXIV t.i.d. po.

(1I) R. T. Th. Age 48 Male Admission January 31. Diag: Pos tencephalitic synarome.

Symptoms: Spasticity of right leg and am. Laggin gait. Mask facies. Dismissed: unimproved.

Onset: Incephalitis. Influenzae in 1920.

Treatmant: $\mathrm{Tr}$. Stram. Gtt XI t. i. d. po.

(12) F. S. Age 18 Fomale. Admission July 1930.

Diag: Postencephalitis tramor.

Dismissed: Same date.

Symptors: Right arm rigid. Iremor in ight hand spesch slow. Onset: Encephalitis - 1921. $30 \mathrm{hr}$ uncon. following mastoid operation. Treatment: Mr. Stramonium gtt XX $5 x$ a day.

\section{DISPEISARY CASES STUDIED AND RISPORTHD}

Case I. Miss I. R. Age 26.

Diag: Postencephalitic Parkinsonism with oculogyric crises. Course and Prognos is, favorable with rigidity, eye deviation, and sialorrhea controlled.

Symptoms: rigidity, sialorrhea, tremor of jaw, tongue, wrists and feet, mask-like facias, spastic gait, retropulsion, oily haix and skin. Onset of encephalitis: November 1925 with morbid insonila for 148 hours, then lethargic state for one and one-half waks. She noted drooping of eyelids and slowing of work in $192 \%$.

Trea tmant: Mr. Stramoni um 160 drops 3 times a day. Tolerance.

Case II. H4158\%. Mr.P. P. Age 31. Diagnosis: Chronic encephalitis with Parizinsonian syarome. Course and Progmosis: Some progress under stramonium lessened rigidity.

Symptoms: Rigiaity, slow speech. Sialorrhed, no retropulsion. Onset of encephalitis: Influenza in 1917 wile in the arny; moderate He noticed rigidity and salivation early in 1925 with slowing at his work, so that he lost job after job. 


\section{BIELIOGRAPHY}

1. AIpers, B. J. - Journal of Nervous and HentaI Disease, 72:257-265. September 1930.

2. Enders, J. H. and Boston, I. N. - Medical Diagnosis, Textbook, W. B. Saunders Company 1925. P.908 P.1336.

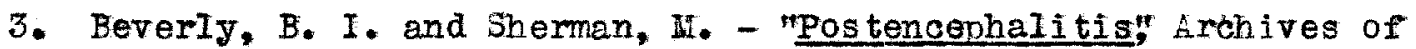
Neurology and Psychiatryt VoI. 13. P.265 1925.

4. Barker, I. F. - Postencephalitis, Medical Clinics of North America Vol.14 131-148. July 1930.

5. Bland and Goldstein. J. A. M. A., Vol. 94., (An originial paper) P. 473 .

6. BramwelI, Edwin - Encephalitis Lethargiaa, Nelson's Ioose-Ieaf., Thomas NeIson and Sons 1931.

7. Glendening, Logan - Mo derm Methods of Treatment, Nextbook, Fourth Edition 1929., G. V. Mosley Company

8. Critchley, McDonald - Postencephalitis and Differential Diagnosis, Brain - VoI.52-I., P24-68, 1930 - I93I.

9. Cruchet, R. - Lancet VoI. I:1285-1287. June 14, I930.

10. Davis, T. K. - Diseases of the Nervous System, NeIson's Medical Service. Thomas Nelson \& Sons:1931. P.374-375 and P.704-705.

11. Duncan, A. G. - Sequela of Encephalitis Lethargica, Archives of Neurology and Psychiatry. V0I. 13: P.40I-402. 1925.

I2. Haves, E. C. Crall, II. Bi. - Brain, VoI.IIII., Part I, P.56 (1930).

13. Ebaugh and strecker - Nextbook of Clinical Psychiatry, (Second Editionl 1928. P. Blakiston's Son and Company.

14. Editorial Answer. On Treatment, J. A. H. A. Vo1.94. Page 206.

I5. Gordon, R. G. - Case of Postencephalitic Respiratory Disorder,

Tol. 8:32-1927-28 Page 340.

16. Hill, T. R.- The Journal of Neurology and Psychopathology, Vol.IX ApriI 1929. Number 36 P. 337-346.

17. Hill, T. R. - Journel of Heunology and Psychopathology, Vol.IX JuIy 1928. Number 33. P. I-10.

18. Hohmann, I. B. - Histo-pathology of Pos tencephalitic Parixinson's Syndrome, Bulletin Johns Hopkins Tospital. 36:P.403 (1925)

19. Foffman, H. and Wohlwili, $P$. - Joumal Of Nervous and NentaI

Disease. VoI. 73 - Rumber 1 January 1931. P.96. 
20. Folt, I. E. and Fowland, J. - The Disease of Infanoy and Thildhood, Textbook: 9 th Edition 1929. D. Appleton and Company P. 647.

21. Hunt, J. R. - Paralysis Agitans, Nelson's Loose-Leaf: Thomes Nelson and Sons. I931. P.596-610.

22. Jacobson and Epplen - J.A. 11. A. VoI.95. (Abstract of Articlel P.1047

23. Jelliffe, 3. E. - Oculogtric Grises, Archives of Neurology and Psychiatry, 21:49I-532. Warch 1929.

24. Leroy - Acute Encephalitic Parkinsonism, Archives of Neurology and Psychiatry. Tol.13: P849: 1925.

25. Mayo Olinic and Mayo Foundation, Collected Papers: VoI.XVI - 1924. T. B. Saunders Company P. 90I-913.

26. MoAlpine - Archives of Teurology and Psychiatry Vol. 12 P.700. 1924.

27. MoKinley, J. O. and Gowan, L. R. - Pathology of Postencephalitis, Archives of Heurology and Psychiatry 15:P.I January 1926.

28. Michels, N. A. - Round Cell Infiltration in Polionvelitis and Encephalitis Nebr. Led. Journal, 14:P.149-151. April 1929.

29. Hocrae, Thomas (Oslerl. Textbook of Medicine 1930 P.974-978 and P.1093-1095.

30. Wuskens, I. J.J: - Pathology of Postencephalitic Ocular Disturbances Journal of Neurology and Psychopathology Vol.8:30 P.132 1927-28.

3I. Olkon, D. M. - Postencenhal it is livas thenia, Archives of Heurology and Psychiatry. P.570-573. September 1930 .

32. Patry, F. J. - Diagnosis and Preatment of Pos tencenhalitis, J. of Tervous and Mental Diseases. 69:617-641. June 1929.

33. Patton, J. M. - Ooulostric Crises - Eves, Nebraska lieỏ. Journal. $4: 265$. September 1919.

34. Pollock, I. J. and Davis I. - Gases of Postencephalitis, Archives of Neurology and PSychiatry Vol. 23. P. 303. 1929.

35. Riley, H. A. - Epidemic Encephalitis, Archives of Neurology and Psychiatry. V01.24:3. P. 574-604. September 1930 .

36. Rivers, T. M. J. A. M. A. 92:1147-1152 February 15, 1929.

37. Rusetzky, I. I. - Ga and Mg chloride on Huscle Tone, abstracted in Arch. of Neuro. and Psych. VoI.23: P.178. 1928.

38. Sands, J. J. - Typhoid Protein Therapy, J. A. I. A. 92:124I-I243. April 1929.

39. Schuster, P. - Journal of Nervous and Mental Disease, Vol. 73 Number 1 January 193I. P.99. 
40. Trautmann, E. and Pansdorf, H. - J. A. H. A. (Abstract from an original paperl Vol. 95 P.1302 1930-3I.

41. Turner, T. A. and Critonley, H. - Postencephalitic Respiratory Disorders

42. Wechsler, I. S. - Textbook Clinicel Neurology. W. B. Saunders Company 1930. P.386 and P.509 - 520.

43. Wigton, H. A. - Parkinsonian Symaromes, Nebreska Medical Journal. Vo 1. IX Number 9. r.345 1925.

44. Vigton, H. A. Person aI Statements. An interview in our Dispensary April 8, 1931 .

45. Wilson, S. A. Z. - Early Study of Encephalitis Iancet 2:7 July $6,1918$.

46. Tood, F. O. - Delafield and Prudden - Textbook of Pathologx. 14th Edition William Nood Company P.1194 - 1196. 1927.

47. Young, A. W. - Parkinsonian Syndromes Journal of lieurology and Psychopathology. Tol.8. P.9-18 I92\%-28.

48. Ziegler, I. H. - Follow-tup Studies - Postencephalitis. J. A. A. A. $91: 138$ - 141. July 2I, 1928. 